\title{
PENAMPILAN PRODUKSI AYAM BROILER YANG DIBERI PAKAN MENGANDUNG MINYAK BUAH MERAH (Pandanus conoideus Lam.) PADA ARAS YANG BERBEDA
}

\section{PRODUCTION PERFORMANCE OF BROILER CHICKEN FED DIET CONTAINING RED FRUIT OIL (Pandanus conoideus Lam.) AT DIFFERENT LEVELS}

\author{
Abdul Rahman Ollong*, Wihandoyo, dan Yuny Erwanto \\ Fakultas Peternakan, Universitas Gadjah Mada, Jl. Fauna No. 3, Bulaksumur, Yogyakarta, 55281
}

\section{INTISARI}

\begin{abstract}
Penelitian bertujuan untuk mengetahui pengaruh penggunaan minyak buah merah (MBM) pada pakan terhadap penampilan produksi ayam broiler. Delapan puluh ekor ayam broiler umur sehari (DOC) ditempatkan pada empat kelompok perlakuan pakan yang berbeda, yaitu: P0 (pakan kontrol/tanpa penambahan minyak), P1 (2\% MBM), P2 (4\% MBM), dan P3 (6\% MBM). Setiap kelompok perlakuan terdiri dari empat ulangan masing-masing dengan lima ekor. Ayam broiler dipelihara selama 41 hari. Rancangan yang digunakan adalah Rancangan Acak Lengkap (RAL) dengan analisis variansi pola searah dan diuji lanjut dengan Duncan's New Multiple Range Test (DMRT). Hasil penelitian menunjukkan bahwa konsumsi pakan berbeda nyata $(\mathrm{P}<0,05)$ dan tertinggi pada $\mathrm{P} 3(2363,40$ g/ekor/6 minggu $)$ diikuti P2 (2350,40 g/ekor/6 minggu), P1 (2181,80 g/ekor/6 minggu), dan P0 (1931,43 g/ekor/6 minggu). Pertambahan bobot badan $(\mathrm{P}<0,05)$ tertinggi pada $\mathrm{P} 2$ (950,45 g/ekor/6 minggu) diikuti oleh P1 (886,08 g/ekor/6 minggu), P3 (856,00 g/ekor/6 minggu), dan P0 (671,70 g/ekor/6 minggu). Konversi pakan (FCR) menunjukkan hasil yang berbeda tidak nyata pada semua perlakuan. Dari hasil penelitian dapat disimpulkan bahwa penggunaan minyak buah merah dalam pakan mampu meningkatkan konsumsi pakan dan pertambahan bobot badan namun tidak berpengaruh terhadap FCR.
\end{abstract}

(Kata kunci: Ayam broiler, Minyak buah merah, Konsumsi pakan, Pertambahan bobot badan, Konversi pakan)

\section{ABSTRACT}

The experiment was conducted to study the effect of red fruit oil (RFO) on production performance of broiler chicken. Eighty day old chicken (DOC) were placed in four groups of different treatments, of from levels of RFO (PO (diet without addition of RFO), P1 (2\% RFO), P2 (4\% RFO) and P3 (6\% RFO)). The treatment group consisted of four replications with five birds each. Broiler chickens were reared for 41 days. Statistical analysis used Completely Randomized Design (CRD) and followed by Duncan's New Multiple Range Test (DMRT). The results showed that feed consumption had significant differences. The highest feed consumption was P3 (2363.40 g/bird/6 weeks) followed by P2 (2350.40 g/bird/6 weeks), P1 (2181.80 g/bird/6 weeks) and P0 (1931.43 g/bird/6 weeks). Moreover, weight gain $(P<0.05)$ also had significant differences and the highest in $P 2(950.45 \mathrm{~g} / \mathrm{bird} / 6$ weeks) then followed by P1 (886.08 g/bird/6 weeks), P3 (856.00 g/bird/6 weeks) and P0 (671.70 g/bird/6 weeks). Feed conversion ratio (FCR) was not significant differences. It could be concluded that the addition of red fruit oil in the diet could improve feed consumption and weight gain but did not affect FCR of broiler chicken.

(Keywords: Broiler chicken, Red fruit oil, Consumption, Weight gain, Feed conversion ratio)

\section{Pendahuluan}

Permasalahan umum yang sering dijumpai dalam memelihara ayam broiler umumnya menyangkut pengadaan pakan, yaitu ketersediaan dan kualitas pakan yang baik. Hal ini bisa terjadi karena ada sebagian bahan pakan unggas (broiler) masih tergantung dari pasokan luar negeri. Tepung ikan dan jagung merupakan contoh bahan pakan

\footnotetext{
* Korespondensi (corresponding author):

Telp. +6281227972620

E-mail: ol96fanindi@gmail.com
}

yang masih diimpor dan merupakan bahan pakan yang sangat penting dalam menyusun pakan.

Penyusunan pakan sering menggunakan minyak sawit sebagai sumber energi dan dianggap mampu menggantikan bahan pakan sumber energi seperti jagung, ada pula yang memanfaatkan lemak hewan tergantung dari tujuan dan ketersediaannya. Lemak sapi (beef tallow) dan poultry fat merupakan salah satu contohnya. Pemanfaatan lemak sapi dan poultry fat sebagai pakan alternatif karena merupakan sumber energi yang sangat potensial, yaitu dengan energi metabolis $7.400 \mathrm{kcal} / \mathrm{kg}$ pada lemak sapi dan $8200 \mathrm{kcal} / \mathrm{kg}$ pada poultry fat (Baiao 
dan Lara, 2005) dan dapat dimanfaatkan dalam pakan unggas yang berumur hingga tiga minggu.

Buah merah (Pandanus conoideus Lam.) merupakan salah satu tanaman obat asli Papua. Usman dan Atekan (2005) cit. Usman (2007) menyatakan bahwa pemanfaatan tepung biji buah merah sebanyak 1 dan $3 \%$ dalam pakan tidak mengganggu pertumbuhan periode starter dan grower ayam buras. Buah merah banyak mengandung tokoferol, alfatokoferol, dan betakaroten yang berfungsi sebagai antioksidan yang mampu menangkal radikal bebas (Anonimus, 2008). Febrina et al. (2007) menyatakan bahwa kandungan bahan aktif yang terdapat pada buah merah cukup beragam dan cukup tinggi sehingga dapat digunakan sebagai pencegah dan juga untuk terapi pengobatan pada beberapa penyakit. Selain itu MBM mengandung betakaroten $700 \mathrm{ppm}$, total karoten $12.000 \mathrm{ppm}$ dan total tokoferol $11.000 \mathrm{ppm}$ (Budi dan Paimin, 2005). Penelitian tentang pemanfaatan penggunaan MBM untuk pakan ayam broiler masih jarang dilakukan, demikian pula data tentang penampilan produksi ayam broiler yang diberi minyak buah merah. Oleh karena itu penelitian dilakukan untuk mengetahui seberapa besar pengaruh MBM terhadap penampilan produksi ayam broiler.

\section{Materi dan Metode}

Penelitian dilakukan di kandang unggas selama 41 hari dan pada Laboratorium Nutrisi dan Makanan Ternak Fakultas Peternakan UGM. Peralatan yang digunakan dalam penelitian antara lain kandang, timbangan kapasitas $10 \mathrm{~kg}$ dan kapasitas $5 \mathrm{~kg}$ (kepekaan $2 \mathrm{~g}$ ), tempat makan dan minum, lampu penerang, unit-unit analisis pendukung lainnya. Pakan perlakuan yang digunakan dibuat secara iso kalori dan iso protein, kandungan nutrien bahan pakan tersaji pada Tabel 1.

Materi penelitian adalah ayam broiler umur sehari (DOC) berjenis kelamin betina strain New Lohmann yang berjumlah 80 ekor dan dibagi dalam empat kelompok perlakuan dan diulang empat kali dengan tiap ulangan menggunakan lima ekor broiler. Empat macam perlakuan yang diberikan adalah 1). perlakuan kontrol (P0) yaitu tanpa menggunakan $\mathrm{MBM}$; 2). perlakuan $\mathrm{P} 1$ : pakan dengan 2\% MBM; 3). perlakuan P2: pakan dengan 4\% MBM; dan 4). perlakuan P3: pakan dengan 6\% minyak buah merah.

\section{Parameter pengamatan}

Konsumsi pakan. Konsumsi pakan (g/ekor) dihitung berdasarkan pakan yang disediakan dikurangi sisa dari pakan yang diberikan selama enam minggu.

Pertambahan bobot badan (PBB). Pertambahan bobot badan (g/ekor) ayam broiler ditimbang setiap minggu selama enam minggu untuk mendapatkan data bobot badan, data total PBB didapat dari penimbangan bobot badan akhir dikurangi bobot badan awal.

Feed conversion ratio (FCR). Feed conversion ratio atau konversi pakan dihitung selama enam minggu berdasarkan banyaknya pakan yang dikonsumsi dibagi dengan PBB.

Tabel 1. Susunan dan kandungan nutrien pakan percobaan yang mengandung minyak buah merah (composition and nutrient content of experimental diets that containing red fruit oli)

\begin{tabular}{|c|c|c|c|c|}
\hline \multirow{2}{*}{ Bahan penyusun (feed ingredients) } & \multicolumn{4}{|c|}{ Level minyak buah merah (\%) (red fruit oil level (\%)) } \\
\hline & 0 & 2 & 4 & 6 \\
\hline Jagung (corn) & 56,00 & 44,50 & 33,00 & 23,00 \\
\hline Dedak halus (rice bran) & 17,00 & 24,00 & 31,00 & 39,00 \\
\hline Tepung ikan (fish meal) & 9,00 & 9,00 & 9,00 & 9,00 \\
\hline Bungkil kedelai (soybean meal) & 15,50 & 15,50 & 15,50 & 15,50 \\
\hline Pollard & 0,50 & 1,00 & 1,50 & 1,50 \\
\hline Minyak buah merah (red fruit oil) & 0,00 & 2,00 & 4,00 & 6,00 \\
\hline Premix & 2,00 & 2,00 & 2,00 & 2,00 \\
\hline Filler & 0,00 & 2,00 & 4,00 & 4,00 \\
\hline Jumlah (total) & 100,00 & 100,00 & 100,00 & 100,00 \\
\hline $\begin{array}{l}\text { Energi metabolisme } \quad(\mathrm{kcal} / \mathrm{kg}) \quad \text { (metabolisable } \\
\text { energy }(\mathrm{kcal} / \mathrm{kg})\end{array}$ & 3011,27 & 3007,82 & 3004,38 & 3071,57 \\
\hline Protein kasar (\%) (crude protein (\%)) & 19,14 & 19,10 & 19,06 & 19,20 \\
\hline Serat kasar (\%) (crude fiber (\%)) & 3,11 & 3,18 & 3,24 & 3,35 \\
\hline Lemak kasar (\%) (ether extract (\%)) & 5,19 & 5,81 & 6,42 & 6,98 \\
\hline Kalsium (\%) (calcium (\%)) & 1,49 & 1,56 & 1,64 & 1,72 \\
\hline Fosfor $(\%)($ phosphorus $(\%))$ & 1,01 & 1,08 & 1,15 & 1,23 \\
\hline
\end{tabular}




\section{Analisis data}

Data yang diperoleh dianalisis menggunakan analisis variansi Completely Randomized Design dengan $\mathrm{N}$ tidak sama (unequal), karena terdapat missing data pada P3 akibat kematian. Uji beda mean dengan uji Duncan's New Multiple Range Test/DMRT (Steel dan Torrie, 1993).

\section{Hasil dan Pembahasan}

\section{Konsumsi pakan}

Hasil analisis statistik menunjukkan terdapat perbedaan nyata pengaruh perlakuan $(\mathrm{P}<0,05)$ terhadap konsumsi pakan. Penggunaan MBM dalam pakan mampu meningkatkan konsumsi pakan ayam broiler (Tabel 2). Tingkat konsumsi pakan dengan level MBM 0 dan 2\% menunjukkan bahwa peningkatan aras 2\% MBM belum menunjukkan pengaruhnya.

Penggunaan MBM dalam pakan pada aras 4 dan 6\% mampu meningkatkan konsumsi pakan dibandingkan dengan kontrol. Baiao dan Lara (2005) menyatakan bahwa ayam broiler betina yang mengkonsumsi pakan yang mengandung vegetable oil (minyak yang berasal dari tanaman) memiliki kecenderungan tingkat konsumsi yang lebih baik dan berdampak pada bobot badan yang dihasilkan, hal ini dipengaruhi oleh tingginya kandungan beberapa jenis asam lemak rantai panjang yang kaya kandungan trigliserida. Di samping itu penambahan MBM tidak berdampak negatif terhadap kemampuan atau daya cerna pada saluran pencernaan ayam broiler. Tokoferol yang terkandung pada MBM berperan membantu pencernaan (Budi dan Paimin, 2005).

Cifti et al. (2005) menyatakan bahwa penambahan Anise oil dalam pakan hingga $400 \mathrm{mg} / \mathrm{kg}$ tidak berbeda dibanding kontrol, diduga karena kandungan nutrien yang sama serta kecilnya perbedaan aras minyak tidak mempengaruhi konsumsi pakan, hal ini menjelaskan mengapa tidak terdapat perbedaan tingkat konsumsi antara level MBM 0 dan 2\% serta antara 4 dan 6\%. Baiao dan Lara (2005) menyatakan bahwa faktor utama dari efek penambahan minyak dalam pakan adalah tingkat kecernaan yang sangat tergantung dari banyak faktor di antaranya komposisi pakan itu sendiri, panjang rantai karbon, komposisi asam lemak bebas, dan banyaknya ikatan rangkap.

\section{Pertambahan bobot badan (PBB)}

Hasil analisis statistik menunjukkan bahwa aras MBM berpengaruh nyata $(\mathrm{P}<0,05)$ terhadap PBB selama penelitian (Tabel 3). Pertambahan bobot badan pada perlakuan pemberian minyak lebih tinggi dibanding kontrol.

Pertambahan bobot badan pada treatment MBM 2-6\% lebih tinggi dibanding control, diduga disebabkan adanya penambahan minyak dalam pakan, karena mampu meningkatkan ketersediaan dan kecernaan nutrien pakan dalam saluran pencernaan ayam broiler, dan berdampak pada perbaikan kecernaan sehingga PBB yang dihasilkan berbeda. Hal ini sejalan dengan pendapat Fadilah et al. (2007) dan Wahju (2004) yang menyatakan bahwa minyak atau lipida mempunyai peranan yang sangat penting dalam pertumbuhan ayam, dalam hal ini berfungsi sebagai sumber energi, membantu absorpsi vitamin yang larut dalam lemak, mengurangi sifat berdebu dalam pakan dan mungkin juga membantu palatabilitas makanan, juga berfungsi sebagai sumber panas.

Wahju (2004) menyatakan bahwa penambahan lemak dalam pakan dapat meningkatkan daya cerna pakan dalam usus. Penambahan minyak dalam pakan meningkatkan kandungan lemak muscular dalam daging yang mampu meningkatkan bobot badan ternak ayam broiler tersebut (Soeparno, 2009).

Penambahan MBM dalam pakan antara 2, 4, dan $6 \%$ tidak menunjukkan adanya perbedaan nyata, diduga karena kecilnya perbedaan aras antara masing-masing perlakuan. Isika et al. (2006) menyatakan bahwa pada penambahan minyak sawit maupun lemak hewan memberikan hasil yang signifikan pada hen day production yaitu 83,4 dan $82,6 \%$ pada penambahan minyak sawit $5 \%$ dan pada broiler fat $2,5 \%$.

Tabel 2. Rerata konsumsi pakan ayam broiler yang diberi pakan mengandung minyak buah merah selama enam minggu penelitian (g/ekor/6 minggu) (average of consumption of broiler chicken fed diet containing red fruit oil (g/bird/six weeks))

\begin{tabular}{|c|c|c|c|c|c|}
\hline \multirow{2}{*}{ Level minyak buah merah (\%) (red fruit oil level (\%)) } & \multicolumn{4}{|c|}{ Ulangan (replication) } & \multirow{2}{*}{$\begin{array}{c}\text { Rerata } \\
\text { (average) }\end{array}$} \\
\hline & $\mathrm{I}$ & II & III & IV & \\
\hline 0 & 1819,10 & 1710,20 & 2032,20 & 2164,20 & $1931,43^{\mathrm{a}}$ \\
\hline 2 & 1924,30 & 2039,10 & 2350,00 & 2413,80 & $2181,80^{\mathrm{ab}}$ \\
\hline 4 & 2108,00 & 2426,60 & 2357,60 & 2509,40 & $2350,40^{\mathrm{b}}$ \\
\hline 6 & 2625,80 & 2037,60 & 2426,80 & - & $2363,40^{\mathrm{b}}$ \\
\hline
\end{tabular}

\footnotetext{
${ }^{\mathrm{a}, \mathrm{b}}$ Superskrip yang berbeda pada kolom yang sama menunjukkan perbedaan yang nyata $(\mathrm{P}<0,05)$ (different superscript at the same column indicate significant defferences $(P<0.05))$.
} 
Tabel 3. Rerata pertambahan bobot badan (PBB) ayam broiler yang diberi pakan mengandung minyak buah merah selama enam minggu (g/ekor/6 minggu) (average of weigth gain of broiler chicken fed diet containing red fruit oil (g/bird/six weeks))

\begin{tabular}{cccccc}
\hline \hline \multirow{2}{*}{ Level minyak buah merah (\%) (red fruit oil level (\%)) } & \multicolumn{4}{c}{ Ulangan (replication) } & \multirow{2}{*}{ Rerata (average) } \\
\cline { 2 - 6 } & I & II & III & IV & \\
\hline 0 & 856,00 & 589,00 & 753,80 & 488,00 & $671,70^{\mathrm{a}}$ \\
2 & 791,50 & 907,00 & 913,80 & 932,00 & $886,08^{\mathrm{b}}$ \\
4 & 986,90 & 907,00 & 930,50 & 977,40 & $950,45^{\mathrm{b}}$ \\
6 & 927,00 & 766,00 & 875,00 & - & $856,00^{\mathrm{b}}$ \\
\hline
\end{tabular}

${ }^{\mathrm{a}, \mathrm{b}}$ Superskrip yang berbeda pada kolom yang sama menunjukkan perbedaan yang nyata $(\mathrm{P}<0,05)($ different superscript at the same column indicate significant defferences $(P<0.05))$.

Tabel 4. Rerata FCR ayam broiler yang diberi pakan mengandung minyak buah merah selama enam minggu (average of FCR of broiler chicken fed diet containing red fruit oil in six weeks)

\begin{tabular}{|c|c|c|c|c|c|}
\hline \multirow{2}{*}{ Level minyak buah merah (\%) (red fruit oil level (\%)) } & \multicolumn{4}{|c|}{ Ulangan (replication) } & \multirow{2}{*}{ Rerata (average) } \\
\hline & I & II & III & IV & \\
\hline 0 & 2,13 & 2,90 & 2,70 & 4,43 & 3,04 \\
\hline 2 & 2,43 & 2,25 & 2,57 & 2,59 & 2,46 \\
\hline 4 & 2,14 & 2,68 & 2,53 & 2,57 & 2,48 \\
\hline 6 & 2,83 & 2,50 & 2,77 & - & 2,70 \\
\hline
\end{tabular}

Hasil yang berbeda ditemukan Theedens (2002), menyatakan bahwa penggunaan minyak sawit tidak memberikan pengaruh yang nyata terhadap PBB ayam broiler. Udayana (2005) juga menyatakan bahwa penambahan tallow (lemak sapi) dalam pakan hingga aras 30\% tidak menyebabkan perbedaan nyata terhadap PBB ayam broiler. Ciftci et al. (2005) dalam penelitiannya menemukan bahwa penambahan minyak esensial hingga 400 $\mathrm{mg} / \mathrm{kg}$ anise oil dalam pakan mampu mempertahankan kecernaan nutrien pakan dalam saluran pencernaan ayam broiler sehingga berdampak positif pada PBB harian ayam broiler (95,45 g/ekor/hari) dan berbeda tidak nyata dengan kontrol $(93,69 \mathrm{~g} / \mathrm{ekor} / \mathrm{hari})$ pada minggu ketiga.

\section{Feed conversion ratio (FCR)}

Hasil analisis statistik data FCR menunjukkan bahwa penambahan MBM tidak menunjukkan pengaruh nyata walaupun PBB menunjukkan hasil yang signifikan demikian pula konsumsi pakan (Tabel 4).

Penambahan aras minyak dari 2 hingga $6 \%$ (Tabel 4) dalam pakan belum mampu memperbaiki nilai konversi pakan ayam broiler dan menunjukkan tidak adanya perbedaan yang nyata dengan pakan kontrol. Artinya kandungan nutrien seperti protein kasar, asam-asam lemak, mineral dan vitamin yang terdapat pada MBM belum memberikan pengaruh pada perbaikan nilai konversi pakan. Bentuk fisik dari pakan yang dikonsumsi, bobot badan ayam serta kandungan nutrien adalah beberapa faktor yang turut berperan dalam nilai konversi pakan (Kartikasari, 2000).
Kisaran nilai FCR yang diperoleh pada penelitian ini adalah 2,46-3,04. Angka konversi ini lebih tinggi bila dibandingkan dengan hasil yang diperoleh Sompie (1995) yang menggunakan minyak kelapa hingga $6,5 \%$ dalam pakan ayam broiler fase finisher dengan konversi pakan berkisar antara 1,86-1,98, demikian pula dengan yang ditemukan Anitha et al. (2006) dengan FCR yang berkisar antara 2,32-2,45 yang memanfaatkan crude rice bran oil hingga $5 \%$ dalam pakan dan tidak berbeda dengan pakan kontrol.

Tabiedian et al. (2005) menyatakan bahwa penambahan minyak kedelai sebesar 2,5\% dan protein $10 \%$ dalam pakan mampu menghasilkan nilai konversi terendah yang berkaitan erat dengan tingginya tingkat konsumsi pakan pada ayam broiler yang berumur 7-21 hari yaitu 1,66 namun berbeda tidak nyata dengan kontrol $(1,76)$, demikian juga hasil yang diperoleh Zulkarnain (2008) dengan nilai FCR berada pada kisaran 1,82-2,10.

\section{Kesimpulan}

Berdasarkan hasil penelitian maka dapat disimpulkan bahwa penggunaan MBM di dalam pakan dapat meningkatkan konsumsi pakan dan PBB, namun tidak meningkatkan FCR.

\section{Daftar Pustaka}

Anitha, B., M. Moorthy, and K. Viswanathan. 2006. Production performance of broiler fed with crude rice bran oil. Int. J. Poult. Sci. 5 (11): 1046-1052. 
Anonimus. 2008. Kandungan Buah Merah. Available at http://www.deherba.com/ kandungan-buah-merah.html. Accession date: 28 Agustus 2009.

Baiao, N.C. and L.J.C. Lara. 2005. Oil and fat in broiler. Brazilian J. Poult. Sci. 7(3): 129-141.

Ciftci, M., T. Guler, B. Dalkilic, and O.N. Ertas. 2005. The effect of anise oil (Pimpinella anisum L.) on broiler performance. Int. J. Poult. Sci. 4(11): 851-855.

Budi, I.M. dan F.R. Paimin. 2005. Buah Merah. Cetakan ke-3. Penebar Swadaya. Jakarta.

Fadilah, R., A. Polana, S. Alam, dan E. Parwanto. 2007. Sukses Beternak Ayam Broiler. PT Agromedia Pustaka. Jakarta.

Febrina, E., D. Gozali, dan T. Rusdiana. 2007. Formulasi sediaan emulsi buah merah (Pandanus conoideus Lam.) sebagai produk antioksidan alami. Laporan Penelitian, Penelitian Peneliti Muda (LITMUD) UNPAD. Universitas Padjajaran. Jatinangor.

Isika, M.A., E.A. Agiang, and B.I. Okon. 2006. Palm oil and animal fat for increasing dietary energy. Int. J. Poult. Sci. 5(1): 43-46.

Kartikasari, L.R. 2000. Kinerja, perlemakan dan kualitas daging ayam broiler yang mendapat suplementasi metionin pada pakan berkadar protein rendah. Tesis. Universitas Gadjah Mada.

Sompie, F.N. 1995. Pengaruh pemberian vitamin E, mineral selenium dan kombinasinya dalam pakan yang mengandung minyak tengik terhadap penampilan dan kualitas karkas ayam broiler. Tesis. Universitas Gadjah Mada. Yogyakarta.
Soeparno. 2009. Ilmu dan Teknologi Daging. Gadjah Mada University Press. Yogyakarta.

Steel R.G.D. and J.H. Torrie. 1993. Prinsip dan Prosedur Statistika. Gramedia Pustaka Utama. Jakarta (Terjemahan).

Tabiedian, S.A., G.H. Sadeghi, and J. Pourreza. 2005. Effect of dietary protein level and soybean oil supplementation on broiler performance. Int. J. Poult. Sci. 4(10): 799803.

Theedens, J.F. 2002. Pengaruh strain, sumber energi (minyak dan lemak) dan tipe pakan terhadap penampilan dan kadar lemak ayam broiler. Tesis. Universitas Gadjah Mada. Yogyakarta.

Udayana, A.I.D.G. 2005. Pengaruh penggunaan lemak sapi dalam ransum sebagai pengganti sebagian energi jagung terhadap berat badan akhir dan prosentase karkas Itik Bali. Ejournal Universitas Udayana, 2: 31-85.

Usman. 2007. Pemanfaatan pasta buah merah (Pandanus conoideus Lam) sebagai pakan alternatif ayam buras periode grower. Balai Pengkajian Teknologi Pertanian (BPTP) Papua. Prosiding Seminar Nasional BPTP Papua.

Wahju, J. 2004. Ilmu Nutrisi Unggas. Cet ke-5. Gadjah Mada University Press. Yogyakarta.

Zulkarnain, D. 2008. Pengaruh suplementasi tepung kunyit (Curcuma domestica Val) sebagai bahan antioksidan dalam ransum terhadap performan dan kualitas karkas ayam broiler. Tesis. Universitas Gadjah Mada. Yogyakarta. 